
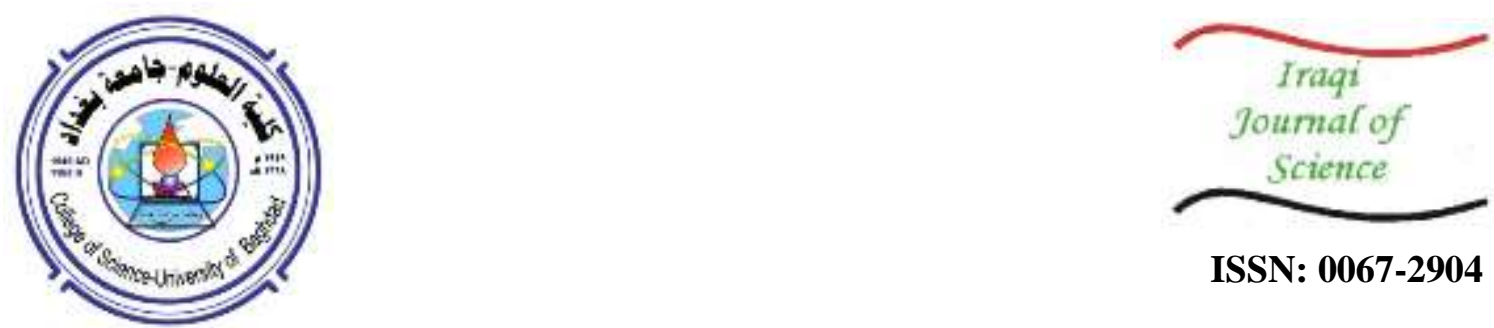

ISSN: 0067-2904

\title{
Effects of Duration and Complications of Type 2 Diabetes Mellitus on Diabetic Related Parameters, Adipocytokines and Calcium Regulating Hormones
}

\author{
Aseel Khalid Thabah Al-Attaby, Makarim Qassim Dawood Al-Lami* \\ Department of Biology, College of Science, University of Baghdad, Baghdad, Iraq
}

Received: $17 / 3 / 2019 \quad$ Accepted: 17/ 7/2019

\begin{abstract}
The present study aims to investigate the effects of duration and complications of type 2 diabetes mellitus on diabetic related parameters, adipocytokines and calcium regulating hormones. This study was conducted on eighty diabetic patients (41 male and 39 female) in Iraq, with an age range of 20-60 years and a disease duration range of 1-180 months. Blood samples were collected from the patients to determine three main types of biomarkers: diabetic-related parameters [Fasting blood sugar (FBS), glycated hemoglobin (HbAlc), insulin, and insulin resistance (IR)]; adipocytokines [adiponectin and tumor necrosis factor- $\alpha$ (TNF- $\alpha$ ), and calcium regulating hormones [parathyroid hormone (PTH), calcitonin, and vitamin D].

The results showed increased levels of some parameters with the increase in duration of disease. Levels of FBS and HbA1c increased significantly $(\mathrm{P}<0.05)$ in the second and the third categories of duration of disease (61-120 and 121-180 month) compared with the first category (1-60 month). Levels of insulin and IR were increased with the increase in duration of disease; this increase was found to be significant $(\mathrm{P}<0.05)$ when a comparison was made between the second and the third categories with the first category. Also, a similar trend was observed when a comparison was made between the third category and the second category. There was a significant $(\mathrm{P}<0.05)$ increase in the levels of TNF- $\alpha$ and calcitonin in the last category compared with the other categories, and a significant $(\mathrm{P}<0.05)$ increase in vitamin $\mathrm{D}$ levels in the last category compared with the first category. Nonsignificant $(\mathrm{P}>0.05)$ differences were found in the levels of adiponectin and PTH among all categories of duration of disease.

When a comparison was made between the two groups of patients (with complications and without complications), a significant $(\mathrm{P}<0.05)$ increase was found in the levels of FBG, HbA1c, insulin, and IR in patients with complications as compared with patients without complications. A significant $(\mathrm{P}<0.05)$ decrease was found in calcitonin levels in patients with complications as compared with patients without complications. Non-significant $(\mathrm{P}>0.05)$ differences were found in the levels of the other parameters (adiponectin, TNF- $\alpha$, PTH and vitamin D) between the two groups of patients.

It can be concluded from the present study that duration of disease affects diabetic related parameters, TNF- $\alpha$ and some calcium regulating hormones (calcitonin and vitamin D), while complications of disease affect diabetic related parameters and calcitonin. It can be suggested that the duration of diabetes is one of the strongest determinants of complication risk.
\end{abstract}

Keywords: diabetes mellitus, complications, adipocytokines, calcium regulating hormones 


\title{
تأثير مدة ومضاعفات مرض السكري النوع الثاني على المعايير ذات العلاقة بالسكري، المحركات الدهنية الخلوية والهرمونات المنظمة للكالسيوم
}

\author{
اسيل خالا ذباح العتابي ، مكارم قاسم داود اللامي"

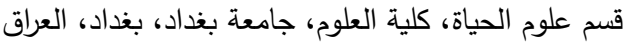

$$
\begin{aligned}
& \text { الخلاصة } \\
& \text { تهدف الدراسة الحالية الى التحري عن تأثير مدة ومضاعفات مرض السكري النوع الثاني على المعايير }
\end{aligned}
$$

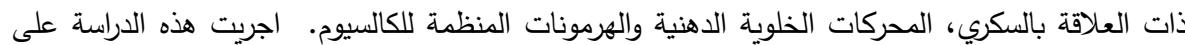

$$
\begin{aligned}
& \text { ثمانين مريضا في العراق مصابا بداء السكري (41 ذكور و } 39 \text { اناث) مدى اعمارهم (20-60 سنة) ومدى } \\
& \text { مدة المرض (1-180 شهر). جمعت عينات الدم من المرضى لتحديد الانواع الثلاثة الرئيسية للمعلمات } \\
& \text { الحيوية: المعايير ذات العلاقة بالسكري [سكر الدم الصائم (FBG)، خضاب الدم السكري (HbA1c)، }
\end{aligned}
$$

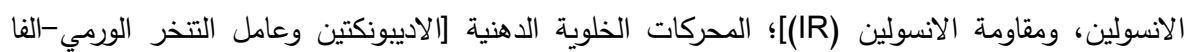

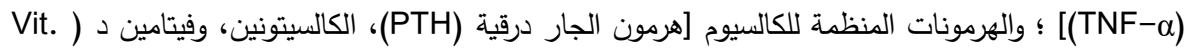

$$
\begin{aligned}
& \text {. [(D } \\
& \text { اظهرت النتائج زيادة مستويات بعض المعايير مع زيادة مدة المرض. اظهرت مستويات سكر الدم الصائم }
\end{aligned}
$$

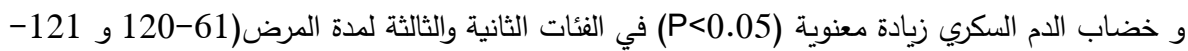

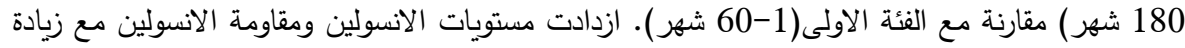

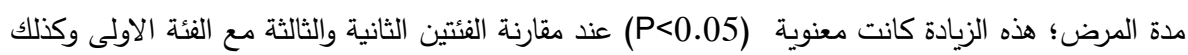

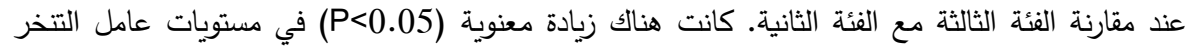

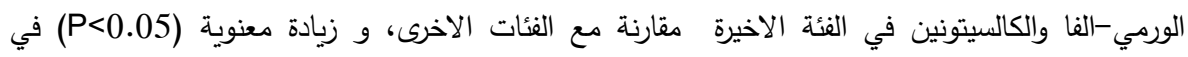

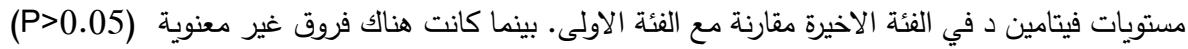

$$
\begin{aligned}
& \text { في مستويات الاديبونكتين وهرمون الجار درقية ضمن جميع فئات مدة المرض. }
\end{aligned}
$$

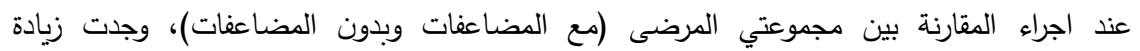

$$
\begin{aligned}
& \text { معنوية (P<0.05) في مستويات سكر الدم الصائم ، خضاب الدم السكري ، الانسولين، ومقاومة الانسولين }
\end{aligned}
$$

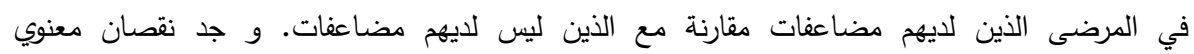

$$
\begin{aligned}
& \text { (P<0.05) }
\end{aligned}
$$

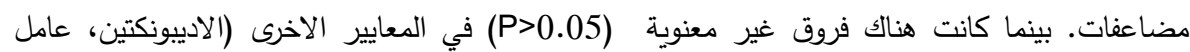

$$
\begin{aligned}
& \text { التخر الورمي-الفا ، هرمون الجار درقية ، و فيتامين د) بين مجموتي المرضئ. } \\
& \text { من الدراسة الحالية بالامكان الاستتناج ان مدة المرض تؤثر على المعايير ذات العات العلاقة بالسكري، عامل }
\end{aligned}
$$

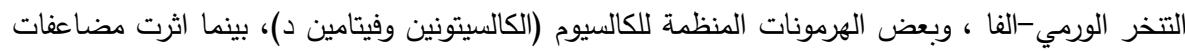

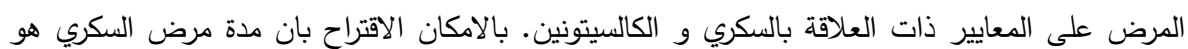

$$
\begin{aligned}
& \text { احد العوامل المحددة لمخاطر المضاعفات. }
\end{aligned}
$$

\section{Introduction}

Diabetes mellitus (DM) is a common metabolic condition resulting in hyperglycemia and hyperglycemia-related chronic complications [1]. Glucose control remains a major focus in the management of patients with type 2 diabetes mellitus (T2DM). Glycated hemoglobin (HbA1c) gives a retrospective assessment of the mean plasma glucose concentration during the preceding 6-12 weeks. In diabetic patients, plasma levels of insulin would be expected to be raised and T2DM results from insulin resistance (IR) [2, 3].

Adipose tissue plays an important role in IR syndrome through the dysregulated production and secretion of adipocytokines, including adiponectin, tumor necrosis factor (TNF), leptin, and resistin [4]. Adiponectin is known to have a regulatory effect on the metabolism of glucose and lipid; it has 
antidiabetic properties [5]. The assessment of TNF- $\alpha$, which affects lipid metabolism and IR, could be beneficial in early detection of T2DM and prevention of its unfavorable complications [6].

Three hormones are considered to be essential in the regulation of calcium homeostasis: parathyroid hormone (PTH), calcitonin, and vitamin D [7]. PTH increases blood levels of calcium by stimulating bones to release calcium, kidney to reclaim calcium from urine, and intestine to absorb calcium [8]. Most studies suggest that high level of PTH is associated with abnormal glucose metabolism and is related with the prevalence of DM [9]. Calcitonin has the opposite effect of PTH; it decreases osteoclastic activity and slows calcium release from bone [3]. It has been reported that calcitonin decreases insulin activity and promotes the development of IR [10]. Vitamin D increases body's uptake of calcium from food and the release of calcium from the bones [8]. Low levels of vitamin D are associated with T2DM by impaired glucose metabolism and insulin sensitivity [11].

The duration of diabetes are significant predictors for development of severe hyperglycemia in the patients with T2DM [12]. Type 2 diabetes is considered as a major cause of mortality and morbidity for its micro-vascular (retinopathy, nephropathy, and neuropathy) and macro-vascular (coronary heart disease, peripheral vascular disease, and stroke and amputation) complications [13]. It was stated that complications of diabetes were present in approximately $30 \%$ of patients at clinical diagnosis of T2DM [14].

Diabetic retinopathy is accompanied by hyperglycemia, microvascular damage, inflammation, vascular permeability, and occlusion; all together resulting in blindness [15]. Diabetic nephropathy is clinically defined by the presence of albuminuria. Neuropathy is the most common and least understood complications of diabetes; some patients with T2DM may develop signs of diabetic neuropathy soon after they are diagnosed, while fifty percent of them will experience diabetic neuropathy when they had the disorder for 25 years or more [16].

The present study aims to investigate the effects of duration and complications of type 2 diabetes mellitus on diabetic related parameters, adipocytokines and calcium regulating hormones in a sample of Iraqi patients.

\section{Materials and Methods \\ Patients}

This study was conducted on 80 diabetic patients (41 male and 39 female) with an age range of 20-60 years. The medical history and clinical data of the studied patients were collected to record duration and complications of disease such as retinopathy, neuropathy, nephropathy, and cardiovascular diseases.

\section{Collection of blood samples}

Blood samples $(5 \mathrm{ml})$ were collected from the patients by venipuncture after fasting overnight for $(8-12)$ hours. The blood samples were divided into two aliquots $(2$ and $3 \mathrm{ml})$. The first aliquot was dispensed for vacuum tube containing EDTA and used for the estimation of HbA1c. The second aliquot was dispensed in a vacuum gel plain tube and left to clot at room temperature; then, it was centrifuged at $3000 \mathrm{rpm}$ for 10 minutes to collect serum that was transferred to eppendrof tubes and stored at $-20^{\circ} \mathrm{C}$ until used.

\section{Measurement of diabetic-related parameters}

Fasting blood glucose (FBG) was measured by an enzymatic colorimetric method with a commercially available kit (Spinreact, Spain). Determination of HbA1c and insulin levels was performed with an available kit (Roche, Germany) using Roche Diagnostics Cobas e 411 analyzer. The homeostasis model assessment (HOMA) was used to quantify IR and calculated by using the following equation:

$$
\text { Glucose }(\mathrm{mg} / \mathrm{dl}) \times \text { Insulin }(\mu \mathrm{IU} / \mathrm{ml})
$$

\section{HOMA $($ IR $)=$}

\section{5}

\section{Estimation of adipocytokines}

Adiponectin and TNF- $\alpha$ levels were measured with available kits (Shaghai, China and Demeditec, Germany, respectively) using the enzyme-linked immune sorbent assay (ELISA) technique.

\section{Determination of calcium regulating hormones}

Parathyroid hormone and calcitonin levels were estimated with available kits (Roche, Germany,) using Roche Diagnostics Cobas e 411 analyzer, while vitamin D level was estimated with available kit (Euroimmun, Germany) using ELISA technique. 


\section{Statistical analysis}

The statistical analysis was performed using the statistical package of social sciences (SPSS), version 18 , and a computer software. Data were expressed as mean \pm standard error (mean $\pm \mathrm{SE}$ ), and a $\mathrm{p}$ value of $<0.05$ was considered significant. Differences between the groups were analyzed using the analysis of variance (ANOVA) test, whereas the least significant difference (LSD) test was used to analyse significant differences between means.

\section{Results and Discussion}

\section{Effect of duration of disease on diabetic-related parameters}

The effect of duration of T2DM disease on diabetic-related parameters is summarized in Table- 1 . The results clarified that the levels of FBS and HbA1c were significantly $(\mathrm{P}<0.05)$ increased in the second and the third categories of duration of disease (61-120 and 121-180 month) compared with the first category (1-60 month). The results showed increased insulin and IR levels with the increase in the duration of disease; this increase was found to be significant $(\mathrm{P}<0.05)$ when a comparison was made between the second and the third categories with the first category, as well as when a comparison was made between the third category and the second category.

Table 1-Effect of duration of disease on diabetic-related parameters in T2DM patients

\begin{tabular}{|c|c|c|c|c|}
\hline \multirow{2}{*}{$\begin{array}{c}\text { Parameters } \\
(\text { Mean } \pm \text { SE) }\end{array}$} & \multicolumn{3}{|c|}{ Duration of disease (month) } & \multirow{2}{*}{ LSD value } \\
\cline { 2 - 5 } & $\mathbf{1 - 6 0}^{*}$ & $\mathbf{6 1 - 1 2 0}$ & $\mathbf{1 2 1 - 1 8 0}$ & \\
\hline FBS (mg/dl) & $184.19 \pm 12.52^{\mathbf{b}}$ & $252.45 \pm 24.46^{\mathbf{a}}$ & $255.31 \pm 29.39^{\mathbf{a}}$ & $54.935^{*}$ \\
\hline $\mathrm{HbA1c}(\%)$ & $8.43 \pm 0.31^{\mathbf{b}}$ & $9.46 \pm 0.56^{\mathbf{a}}$ & $9.76 \pm 0.40^{\mathbf{a}}$ & $1.008^{*}$ \\
\hline Insulin $(\mu \mathrm{u} / \mathrm{ml})$ & $31.34 \pm 7.07^{\mathbf{c}}$ & $63.51 \pm 44.27^{\mathbf{b}}$ & $94.26 \pm 35.11^{\mathbf{a}}$ & $16.431^{*}$ \\
\hline HOMA (IR) & $14.54 \pm 3.63^{\mathbf{c}}$ & $41.49 \pm 31.63^{\mathbf{b}}$ & $59.24 \pm 44.41^{\mathbf{a}}$ & $17.502^{*}$ \\
\hline
\end{tabular}

- Means in rows carrying similar small letters indicate non-significant differences $(\mathrm{p}<0.05)$.

- Means in rows carrying different small letters indicate significant differences $(\mathrm{P}<0.05)$.

* $(\mathrm{P}<0.05)$.

Duration of diabetes is one of the strongest determinants of complication risk. A positive correlation between FBS and duration of diabetes in this study is in agreement with the results obtained by a previous study [12] which reported that the incidence of severe hyperglycemia increased with age and duration. The concentration of HbA1c in the blood depends on both the lifespan of the red blood cell and the blood glucose concentration [17]. Therefore, the significant increase in the HbA1c level of the T2DM patients in the present study is affected by the duration of disease, which is consistent with a previous study [18]. This finding might be related to the attending physician's inertia in which therapeutic changes are sometimes introduced after several years of uncontrolled HbA1c levels [19].

Regarding the results of insulin and IR, they are in agreement with a previous study [20] which reported that insulin sensitivity correlated inversely with fasting insulin and that insulin level increased with the duration of diabetes. The current finding might be due to the fact that the body becomes more resistant to insulin as the duration of disease increases, in addition to and the effect of drugs which might, with the increase in diabetes duration, decrease cells resistance to insulin [21]. 


\section{Effect of duration of disease on adipocytokines}

As demonstrated in Table-2, no significant differences $(\mathrm{P}>0.05)$ were found in serum adiponectin levels among the three categories of duration of disease, whereas, TNF- $\alpha$ levels were elevated significantly $(\mathrm{P}<0.05)$ in the last category $(121-180$ month $)$ compared with the other categories.

Table 2-Effects of duration of disease on adipocytokines in T2DM patients

\begin{tabular}{|c|c|c|c|c|}
\hline \multirow{2}{*}{$\begin{array}{c}\text { Adipocytokines } \\
(\text { Mean } \pm \text { SE) }\end{array}$} & \multicolumn{3}{|c|}{ Duration of disease (month) } & \multirow{2}{*}{$\begin{array}{c}\text { LSD } \\
\text { value }\end{array}$} \\
\cline { 2 - 4 } & $\mathbf{1 - 6 0}$ & $\mathbf{6 1 - 1 2 0}$ & $\mathbf{1 2 1 - 1 8 0}$ & \\
\hline Adiponectin $(\mu \mathrm{g} / \mathrm{ml})$ & $11.35 \pm 0.53^{\mathbf{a}}$ & $10.50 \pm 0.55^{\mathbf{a}}$ & $11.54 \pm 1.09^{\mathbf{a}}$ & $2.315 \mathbf{N S}$ \\
\hline $\mathrm{TNF}-\alpha(\mathrm{ng} / \mathrm{ml})$ & $103.76 \pm 5.77^{\mathbf{b}}$ & $109.10 \pm 7.46^{\mathbf{b}}$ & $132.91 \pm 17.4^{\mathbf{a}}$ & \multirow{2}{*}{$22.861^{*}$} \\
\hline
\end{tabular}

- Means in rows carrying similar small letters indicate a non-significant difference $(\mathrm{p}<0.05)$.

- Means in rows carrying different small letters indicate a significant difference $(\mathrm{P}<0.05)$.

* $(\mathrm{P}<0.05)$, NS: Non-Significant.

The current results of adiponectin agree with those from a previous study [22] which reported that the decrease of adiponectin levels in type 2 diabetic patients was attributed to factors other than duration of disease, such as obesity. Also, another study [23] found that levels of adiponectin in type 2 diabetic patients were decreased as albuminuria was increasing. It can be suggested that the duration of diabetes is one of the strongest determinants of complication risk.

Concerning TNF- $\alpha$, the present results could be due to the fact that proinflammatory cytokines may be increased by hyperglycemia in subjects with impaired glucose tolerance [24]. This result, however, was strongly confirmed since all diabetics in the present study had elevated serum level of TNF- $\alpha$. The raised level of TNF- $\alpha$ induces IR in adipocytes and peripheral tissues by impairing the insulin signaling through serine phosphorylation that leads to the development of T2DM [25].

Effect of duration of disease on calcium regulating hormones

Table-3 summarizes the effect of duration of disease on calcium regulating hormones in T2DM patients. No significant $(\mathrm{P}>0.05)$ difference was found in PTH level among all categories of duration of disease. However, there was a significant increase $(\mathrm{P}<0.05)$ in calcitonin levels in the last category (121-180 month) compared with the other categories. There was a significant increase $(\mathrm{P}<0.05)$ in vitamin D level in the last category compared with the first category.

Table 3-Effect of duration of disease on calcium regulating hormones in T2DM patients

\begin{tabular}{|l|l|l|l|l|}
\hline \multirow{2}{*}{$\begin{array}{l}\text { Hormones } \\
(\text { Mean } \pm \text { SE) }\end{array}$} & \multicolumn{2}{|l|}{ Duration of disease (month) } & \multirow{2}{*}{ LSD value } \\
\cline { 2 - 5 } & $\mathbf{1 - 6 0}$ & $\mathbf{6 1 - 1 2 0}$ & $\mathbf{1 2 1 - 1 8 0}$ & \\
\hline PTH $(\mathrm{pg} / \mathrm{ml})$ & $47.79 \pm 5.44^{\mathbf{a}}$ & $50.30 \pm 5.14^{\mathbf{a}}$ & $52.10 \pm 7.09^{\mathbf{a}}$ & $5.437 \mathbf{~ N S}$ \\
\hline Calcitonin $(\mathrm{pg} / \mathrm{ml})$ & $1.056 \pm 0.12^{\mathbf{b}}$ & $1.760 \pm 0.47^{\mathbf{b}}$ & $2.62 \pm 1.11^{\mathbf{a}}$ & $0.887^{*}$ \\
\hline Vitamin D (ng/ml) & $15.72 \pm 0.82^{\mathbf{b}}$ & $16.04 \pm 0.56^{\text {ab }}$ & $17.52 \pm 2.09^{\mathbf{a}}$ & $1.503^{*}$ \\
\hline
\end{tabular}

- Means in rows carrying similar small letters indicate a non-significant difference $(\mathrm{p}<0.05)$.

- Means in rows carrying different small letters indicate a significant difference $(\mathrm{P}<0.05)$.

* $(\mathrm{P}<0.05)$, NS: Non-Significant. 
Regarding the present results of PTH, a similar result was also observed by a previous investigation [26] which reported no effects of duration of disease on serum PTH levels. PTH secretion in blood is stimulated by a decrease in ionized $\mathrm{Ca}^{2+}$ and, conversely, PTH secretion is stopped by an increase in ionized $\mathrm{Ca}^{2+}[27]$.

Concerning calcitonin, unlike other hormones, no specific developmental or metabolic abnormalities were associated with a deficiency or excess of calcitonin [28].

A significant increase in the level of calcitonin in the last duration category is in disagreement with a previous report [29] who showed that calcitonin levels remained within the normal range during the entire study period and during the follow-up after several years.

The elevated vitamin $\mathrm{D}$ levels with increased duration of disease can be attributed to the inverse associations between vitamin D levels and FBG. Also, it was mentioned that vitamin D can enhance the synthesis of insulin and its release from the $\beta$-cells; hence, it plays a role in glucose metabolism [30].

\section{Effect of complications on diabetic-related parameters}

Table-4 shows the effect of complications on diabetic-related parameters in T2DM patients. A significant $(\mathrm{P}<0.05)$ increase was found in FBS, HbA1c, insulin and IR levels in patients with complications as compared with patients without complications.

Table 4-Effect of complications of disease (retinopathy, neuropathy, nephropathy, and cardiovascular diseases) on diabetic-related parameters in T2DM patients

\begin{tabular}{|c|c|c|c|}
\hline \multirow{2}{*}{$\begin{array}{c}\text { Parameters } \\
(\text { Mean } \pm \text { SE) }\end{array}$} & With & Without & \multirow{2}{*}{ LSD value } \\
\cline { 2 - 3 } & $234.79 \pm 16.41^{\mathbf{a}}$ & $184.63 \pm 13.94^{\mathbf{b}}$ & $41.677^{*}$ \\
\hline FBS $(\mathrm{mg} / \mathrm{dl})$ & $9.32 \pm 0.31^{\mathbf{a}}$ & $8.39 \pm 0.36^{\mathbf{b}}$ & $0.772^{*}$ \\
\hline HbA1c $(\%)$ & $69.92 \pm 28.81^{\text {a }}$ & $27.03 \pm 7.02^{\mathbf{b}}$ & $9.624^{*}$ \\
\hline Insulin $(\mu \mathrm{u} / \mathrm{ml})$ & $42.56 \pm 19.77^{\text {a }}$ & $12.48 \pm 3.99^{\mathbf{b}}$ & $7.559^{*}$ \\
\hline Insulin Res. $(\mathrm{IR})$ &
\end{tabular}

- Means in rows carrying different small letters indicate a significant difference $(\mathrm{P}<0.05)$.

* $(\mathrm{P}<0.05)$.

The present results of FBG are in agreement with those previously reported [31], which suggested that increased risk of fatal cardiovascular disease is mainly attributed to hyperglycemia. Regarding $\mathrm{HbA1c}$, a similar result has been reported by another study [32] which stated that the complications were significantly associated with the duration of diabetes and $\mathrm{HbA} 1 \mathrm{c}$ level. In patients with T2DM, the risks of the development of microvascular complications determine chronic hyperglycemia and a number of metabolic syndrome components. In accordance with $\mathrm{HbA} 1 \mathrm{c}$ function as an indicator for the mean blood glucose level, HbAlc predicts the risk of diabetic complications in diabetes patients. Whereas, improving the glycemic control could reduce the risk of cardiovascular events in diabetic patients [32].

The present findings of insulin and IR may be explained on the ground that people who develop type 2 diabetes at a younger age have the double burden of severe IR and severe insulin secretory defect and might be more likely to develop microvascular and macrovascular complications [33]. Also, defects in insulin signalling at the level of the IR were implicated in other complications such as diabetic nephropathy and retinopathy [34].

\section{Effect of complications of disease on adipocytokines}


Table-5 shows the effect of complications on some cytokines in T2DM patients. The results revealed that no significant differences $(\mathrm{P}>0.05)$ were found in levels of serum adiponectin and TNF- $\alpha$ in patients with complications as compared with patients without complications.

Table 5-Effect of complications of diseases (retinopathy, neuropathy, nephropathy, and cardiovascular diseases) on adipocytokines in T2DM patients.

\begin{tabular}{|c|c|c|c|}
\hline \multirow{2}{*}{$\begin{array}{c}\text { Adipocytokines } \\
\text { (Mean } \pm \text { SE) }\end{array}$} & \multicolumn{2}{|c|}{ Complications } & \multirow{2}{*}{ LSD value } \\
\cline { 2 - 3 } & With & Without & \\
\hline Adiponectin $(\mu \mathrm{g} / \mathrm{ml})$ & $11.12 \pm 0.64^{\mathrm{a}}$ & $11.32 \pm 0.50^{\mathrm{a}}$ & $0.562 \mathrm{NS}$ \\
\hline $\mathrm{TNF}-\alpha(\mathrm{ng} / \mathrm{ml})$ & $106.92 \pm 7.29^{\mathrm{a}}$ & $114.69 \pm 7.38^{\mathrm{a}}$ & $15.702 \mathrm{NS}$ \\
\hline
\end{tabular}

- Means in rows carrying similar small letters indicate a non-significant difference $(\mathrm{P}<0.05)$.

NS: Non-Significant.

Although the current results revealed that levels of adiponectin and TNF- $\alpha$ were not affected by the presence of diabetic complications, a previous study stated that adiponectin is considered to be a defensive factor in the pathogenesis of a number of processes associated to cardiovascular complications including retinopathy lesions in both diabetics and non-diabetics [14]. Also, another study reported that TNF- $\alpha$ contributes to the impairment of glucose homeostasis, insulin signaling and development of IR and cardiovascular complications [35].

\section{Effect of complications on calcium regulating hormones}

The data presented in Table-6 show a significant $(\mathrm{P}<0.05)$ decrease in calcitonin level in patients with complications as compared with patients without complications. However, no significant differences $(\mathrm{P}>0.05)$ were found in levels of PTH and Vit D between patients with complications and those without complications.

Table 6-Effect of complications of disease (retinopathy, neuropathy, nephropathy, and cardiovascular diseases) on calcium regulating hormones in T2DM patients

\begin{tabular}{|c|c|c|c|}
\hline \multirow{2}{*}{$\begin{array}{c}\text { Hormones } \\
(\text { Mean } \pm \text { SE) }\end{array}$} & \multicolumn{2}{|c|}{ Complications } & \multirow{2}{*}{ LSD value } \\
\cline { 2 - 3 } & With & Without & \\
\hline PTH $(\mathrm{pg} / \mathrm{ml})$ & $46.67 \pm 6.55^{\text {a }}$ & $51.27 \pm 3.96^{\text {a }}$ & 6.023 NS \\
\hline Calcitonin $(\mathrm{pg} / \mathrm{ml})$ & $1.156 \pm 0.15^{\mathbf{b}}$ & $1.791 \pm 0.45^{\mathrm{a}}$ & $0.475^{*}$ \\
\hline Vit. D $(\mathrm{ng} / \mathrm{ml})$ & $15.64 \pm 0.74^{\mathrm{a}}$ & $16.98 \pm 0.81^{\mathrm{a}}$ & $2.166 \mathrm{NS}$ \\
\hline
\end{tabular}

- Means in rows carrying similar small letters indicate a non-significant difference $(\mathrm{p}<0.05)$.

- Means in rows carrying different small letters indicate a significant difference $(\mathrm{P}<0.05)$.

* $(\mathrm{P}<0.05)$, NS: Non-Significant.

The current results of PTH agree with a previous report [36] which stated that high level of PTH is associated with abnormal glucose metabolism in early stages of disease and is related with the predominance of DM, but not in later stages after complications occur. PTH seems to respond only to calcium, whereas calcitonin responds to both calcium as well as gastrointestinal hormones such as gastrin [28]. In the current study, the decreased levels of calcitonin in diabetic patients with complications may be due to that the patients are taking different treatment to control hyperglycemia 
as well as the inhibiting effect of calcitonin on insulin-stimulated glucose consumption by muscles and adipose tissue [10]. Regarding the results of vitamin D, they are in agreement with the result from a previous study [28] which reported that vitamin D levels were significantly lower in the T2DM patients than in the control group regardless of the complications that occur later with T2DM. On the other hand, another study [37] reported that vitamin D deficiency was found to be significantly associated with retinopathy and nephropathy.

In conclusion, this study demonstrated that the clinical history of diabetic patients such as duration and complications of disease affect diabetic related parameters, certain adipocytokines and certain calcium regulating hormones.

\section{Références}

1. Niroomand, M., Ghasemi, S.N., Karimi-Sari, H. and Khosravi, M.H. 2017. Knowledge, attitude, and practice of Iranian internists regarding diabetes: Across sectional study. Diabetes Metab. J., 41: 179-186.

2. Gardner, D.G. and Shoback, D.M. 2011. Pancreatic Hormones and Diabetes Mellitus. Greenspan'S Basic and Clinical Endocrinology. $9^{\text {th }}$ ed. New York: McGraw-Hill Medical. pp. 573-593.

3. Crook, M. A. 2012. Clinical Biochemistry and Metabolic Medicine, 8th Ed.: Hodder Arnold, AN Hachette UK. Company. Section 12: 176-199.

4. Steppan, C.M. 2001. The hormone resist in links obesity to diabetes. Nature, 409: 307-312.

5. Yamauchi, M.D., Bovenkerk, J.E., Juliar, B. E., Watson, W., Kerr, K., Jones, R., Zhu, Q. and Considince, R.V. 2003. Serum resistin (FIZZ3) protein is increased in obese humans. J. Clin. Endocrinol. Metab., 88(11): 5452-5455.

6. Qasim, Q.A., Fareed, Y.Y. and Hassan, J. K. 2017. Evaluation of inflammatory state in diabetic patients by measuring of Interleukin- 6 and tumor necrosis factor- $\alpha$ in obese and non-obese type 2 diabetes mellitus patients as compared with control subjects. Iraqi J.M.S., 15(3): 297-304.

7. Hirsch, P.F., Lester, G.E. and Talmage, R.V. 2001. Calcitonin, an enigmatic hormone: does it have a function. J. Musculo. Skel. Neuron. Interact., 1(4): 299-305.

8. Brown, E.M. 2001. Physiology of Calcium Homeostasis. In: The Parathyroids, Second Editon, JP Bilezikian, R Marcus, and A Levine (eds.); Chapter 10: 167-182.

9. Ivarsson, K.M., Clyne, N., Almquist, M. and Akaberi, S. 2014. Hyperparathyroidism and new onset diabetes after renal transplantation. Transplant. Proc., 46: 145-150.

10. Moisa, B.S.S. 2017. Calcitonin participant in the development of insulin resistance. J. Bio. Sci. Eng., 10(7): 343-354.

11. Gulseth, H.L., Wium, C., Angel, K., Erik, F.E. and Birkeland, K.I. 2017. Effects of vitamin D supplementation on insulin sensitivity and insulin secretion in subjects with type 2 diabetes and vitamin D deficiency: a randomized controlled trial. Diabetes Care, 40(7): 872-878.

12. Yun, J.S. and Ko, S.H. 2016. Risk factors and adverse outcomes of severe hypoglycemia in type 2 diabetes mellitus. Diabetes Metab. J., 40(6): 423-432.

13. Li, S., Zhao, J.H., Luan, J.,Langenberg, C., Luben, R.N., Khaw, K.T., Wareham, N.J. and Loos, R.J. 2011. Genetic predisposition to obesity leads to increased risk of type 2 diabetes. Diabetologia, 54(4): 776-782.

14. Mbata, O., Abo El-Magd, N.F. and El-Remessy, A.B. 2017. Obesity, metabolic syndrome and diabetic retinopathy: Beyond hyperglycemia. World J Diabetes, 8(7): 317-329.

15. Altman, C. and Schmidt, M.H.H. 2018. The role of microglia in diabetic retinopathy: inflammation, microvasculature, defects and neurodegeneration. Int. J. Mol. Sci.,19(1): e110.

16. Vasudevan, D.M. and Sreekumari, S. 2007. Text Book of Biochemistry for Medical Student. $5^{\text {th }}$ Ed., Jaypee Brothers Medical Publishers (P) Ltd. Condition: New. pp. 162.

17. David, B. and Sacks, M.B. 2012. Diabetes mellitus. In: Tietz Textbook of Chemistry and Molecular Diagnostics. Fifth ed., pp. 1415-1450.

18. Ito, H. , Omoto, T., Abe, M., Matsumoto, S., Shinozaki, M., Nishio, S., Antoku, S., Mifune, M. and Togane, M. 2017. Relationships between the duration of illness and the current status of diabetes in elderly patients with type 2 diabetes mellitus. Geriatr. Gerontol. Int., 17(1): 24-30. 
19. 19. Hayashino, Y., Izumi, K., Okamura, S., Nishimura, R., Origasa, H. and Tajima, N. 2017. Duration of diabetes and types of diabetes therapy in Japanese patients with type 2 diabetes: the Japan diabetes complication and its prevention prospective study 3 (JDCP study 3 ). J. Diabetes Investig., 8(2: 243-249.

20. Verma, M., Paneri S., Badi P. and Raman, P.G. 2006. Effect of increasing duration of diabetes mellitus type 2 on glycated hemoglobin and insulin sensitivity. Indian J. Clin. Biochem., 21(1): 142-146.

21. Mohsen, I.H. 2016. Evaluation of Micro RNAs Role in Genetics and Physiological Parameters in Type 2 Diabetes Patients. Ph.D. Thesis, College of Sciences, Babylon University.

22. Al-Saeed, A.H., Maria, I., Constantino, L.M., Mario, D., Gisler, F.L., Luo, C., Wu, T., Twigg, S.M., Yue, D.K. and Wong, J. 2016. An inverse relationship between age of type 2 diabetes onset and complication risk and mortality: The impact of youth-onset type 2diabetes. Diabetes Care, 39(5): 823-829.

23. Georgoulidou, A., Roumeliotis, A., Roumeliotis, S., Thodis, I., Manolopoulos, V., Malindretos, P., Mavromatidis, K. and Passadakis, P. 2017. Adiponectin plasma levels and albuminuria in patients with type 2 diabetes and different stages of diabetic kidney disease. J. Nephrol. Ther., 7: 285.

24. Saud, A.M. 2014. Serum levels of tumor necrosis factor alpha and interleukine-12 in some Iraqi diabetic patients' type 1. Int. J. Curr. Microbiol. App. Sci., 3(4): 260-268

25. Akash, M. S.; Rehman, K. and Liaqat, A. 2018. Tumor necrosis factor-alpha: role in development of insulin resistance and pathogenesis of type 2 diabetes mellitus. J. Cell Biochem., 119(1): 105-110.

26. Abbas, W.A., Al-Zubaidi, M.A., Al-Khazraji, S.Kh. 2012. Estimation of serum calcium and parathyroid hormone (PTH) levels in diabetic patients in correlation with age and duration of disease. Iraqi J. Comm. Med., 2: 161-164.

27. Hassan, S.A., Elsheikh, W.A., Abdel Rahman, N.I. and Elbagir, N.M. 2016. Serum calcium levels in correlation with glycated hemoglobin in type 2 diabetic Sudanese patients. Advances in Diabetes and Metabolism, 4(4): 59-64.

28. Arnold, J.F. and Barton, S.L. 2015. Calcitonin, the forgotten hormone: does it deserve to be forgotten. Clin. Kidney J., 8: 180-187.

29. Lunati, ME., Grancini, V., Colombo, C., Palmieri, E., Resi, V., Perrino, M., Orsi, E. and Fugazzola, L. 2016. Basal and stimulated calcitonin levels in patients with type 2 diabetes did not change during 1 year of liraglutide treatment. Metabolism, 65(1): 1-6.

30. Rafiq, S. and Jeppesen, P.B. 2018. Is hypovitaminosis D related to incidence of type 2 diabetes and high fasting glucose level in healthy subjects: a systematic review and meta-analysis of observational studies? Nutrients, 10(1): E59

31. VinodMahato, R., Gyawali, P., Raut, P.P., Regmi, P., Psd, K. and Singh, DRP. 2011. Association between glycaemic control and serum lipid profile in type 2 diabetic patients: Glycated haemoglobin as a dual biomarker. Biomedical Research, 22(3): 375-380.

32. Chakraborty, N. and Mandal, A. K. 2016. A study on complications of type 2 diabetes mellitus in a diabetes clinic of a tertiary care hospital, Kolkata, west Bengal. IOSR-JDMS, 15(10): 29-33.

33. Ha, K.H., Park, C.Y., Jeong, I.K., Kim, H.J., Kim, S.Y., Kim, W.J.; Yoon, J.S.; Kim, I.J.; Kim, D.J. and Kim, S. 2018. Clinical characteristics of people with newly diagnosed type 2 diabetes between 2015 and 2016: difference by age and body mass index. Diabetes Metab. J., 42(2): 137146.

34. Rajala, R.V., Wiskur, B.M., Tanito, M. Callegan, M. and Rajala, A. 2009. Diabetes reduces autophosphorylation of retinal insulin receptor and increases protein-tyrosine phosphatase-1B activity. Invest. Ophthalmol. Vis. Sci., 50(3): 1033-1040.

35. Lyons, C.L., Kennedy, E.B. and Roche, H.M. 2016. Metabolic inflammation-differential modulation by dietary constituents. Nutrients, 8(5): e247.

36. Rahimi, Z. 2014. Parathyroid hormone, glucose metabolism and diabetes mellitus. J. Parathyr. Dis., 2(1): 55-56.

37. Bajaj, S., Singh, R.P.,Dwivedi, N.C.,Singh, K., Gupta, A. and Mathur, M. 2014. Vitamin D levels and microvascular complications in type 2 diabetes. Indian J. Endocrinol. Metab., 18(4): 537541. 